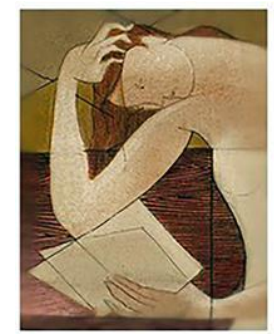

\title{
Movimentos negros e a fragilização territorial: uma revisitação histórica no romance Ponciá Vicêncio, de Conceição Evaristo
}

\begin{abstract}
Mirvana Luz Teixeira ${ }^{1}$
Resumo: O romance Ponciá Vicêncio, publicado em 2003 por Conceição Evaristo, aborda, no largo escopo de pertinentes temas que retrata, a movimentação da população negra ao longo da história. Em diáspora ou em migração, a família apresentada na obra representa um painel da constante exclusão de negros e negras para as margens da sociedade brasileira. Nesse sentido, este estudo visa analisar as trajetórias percorridas por Ponciá - personagem que dá nome à obra -, por seus avós, pais e irmão, tendo em vista que o sequestro em África foi apenas o início de uma série de remoções históricas que devem ser relembradas.
\end{abstract}

Palavras-chave: diáspora; memória; migração.

Abstract: Abstract: The novel Ponciá Vicêncio, published in 2003 by Conceição Evaristo, encompasses, within the broad scope of themes it brings up, the movement of black populations throughout history. Either through diasporas or migrations, the family depicted in this work represents a broad array of the constant exclusion faced by black men and women towards the margins of Brazilian society. In that regard, this study intends on analyzing the trajectories run by Ponciá - character from whom the novels name comes from -, by his grandparents, parents, and brother, considering that African kidnapping was but the beginning to a series of historical displacements which are to be remembered.

Keywords: diaspora; memory; migration.

\author{
Recordar é preciso. \\ O movimento vaivém nas águas-lembranças \\ dos meus marejados olhos transborda-me a vida, \\ salgando-me o rosto e o gosto. \\ sou eternamente náufraga, \\ mas os fundos oceanos não me amedrontam \\ e nem me imobilizam.
}

(Conceição Evaristo)

\section{Considerações iniciais}

No poema "Recordar é preciso", publicado no livro Poemas da Recordação e outros movimentos (2008), Conceição Evaristo apresenta a memória coletiva que os sujeitos negros têm dos navios negreiros que trouxeram de África seus antepassados. A importância da ancestralidade apresentada no poema é percebida em muitas obras de

\footnotetext{
${ }^{1}$ Licenciada em Letras (Português/Inglês). Mestranda em Letras da Universidade Federal do Rio Grande do Sul.
} 


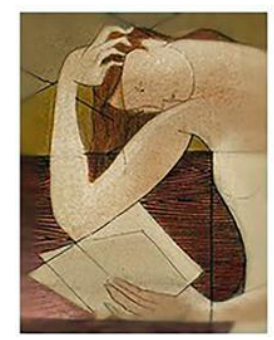

autoras e autores negros que buscam, com a escrita, renovar o cânone literário e apresentar uma perspectiva por muitos anos apagada da história nacional.

O referido apagamento da matriz africana em nossa sociedade é confrontado quando autoras como Evaristo escrevem e apresentam sua racionalidade através da escrita. Essa busca por representação está presente no primeiro romance da autora, Ponciá Vicêncio, publicado em 2003. Nele, o foco recai sobre a trajetória de vida de Ponciá Vicêncio - personagem que dá nome à obra - desde a infância até a vida adulta. A protagonista do romance, mulher negra neta de escravos libertos, carrega consigo a voz de muitas outros sujeitos que, como ela, tiveram seu destino traçado anos antes de seu nascimento, quando seus ancestrais foram submetidos a um sistema que, mesmo depois de, por lei, finalizado, continuou vigorando. A herança da escravidão marca a vida de Ponciá, de seu irmão, de seus pais e avós. Assim como seus antepassados foram sequestrados em África e trazidos ao Brasil, Ponciá, sua mãe e seu irmão migram dentro do território nacional em busca de melhores condições de vida. Todavia, eles acabam encontrando, cada um a seu modo, a periferização, que reatualiza a narrativa de remoção anteriormente vivida por seus ancestrais.

Pensando na história nacional, a luta de populações periferizadas é uma constante, e o deslocamento urbano forçado muitas vezes foi realidade para aqueles que - ao longo da história - foram segregados. A diáspora negra de África ao Brasil foi, portanto, o primeiro movimento representado no romance; em seguida, tem-se a movência do campo à cidade e, na área urbana, ainda é possível perceber como Ponciá e Luandi, seu irmão, foram empurrados em direção aos extremos.

Nesse sentido, o objetivo deste trabalho será observar esses movimentos, marcados por exclusão e sujeição. De acordo com Rogério Haesbaert (2014, p. 17), “a exclusão aviltante ou as inclusões extremamente precárias a que as relações capitalistas relegaram a maior parte da humanidade faz com que muitos, no lugar de partilharem múltiplos territórios, vaguem em busca de um, o mais elementar território da sobrevivência cotidiana". Esse processo de errância, representado por uma desterritorialização constante - material e imaginária - é marcado pela exclusão socioespacial, provocando a manutenção de um sistema análogo à escravidão. 


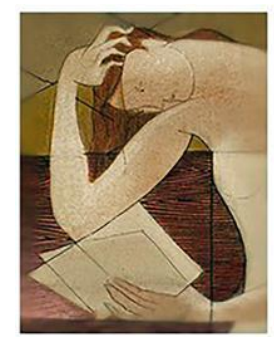

No romance de Conceição Evaristo, o trânsito dos sujeitos negros está bastante presente: após o fim da escravidão, os avós de Ponciá foram libertos, mas continuaram presos às terras de seu antigo senhor - Coronel Vicêncio -, de modo que tanto o pai da personagem como seu irmão permaneceram trabalhando de maneira bastante precária nas terras da família Vicêncio. Além disso, todos eles continuaram carregando o sobrenome do senhor como marca de propriedade daquele. Quando Ponciá migra para cidade, ela trabalha em condições precárias por anos até conseguir comprar um "barraco" no morro da cidade. Seu irmão, por sua vez, trabalha na limpeza de uma delegacia e tem como único alento a amizade de seu chefe, um soldado negro, que serve de inspiração para ele. A mãe, Maria Vicêncio, após a saída dos filhos do campo, passa um longo período de errância por fazendas, até que vai ao encontro deles com a esperança de buscá-los de volta.

A migração de Ponciá, Luandi e Maria do campo para a cidade - bem como a forçada diáspora pela qual seus antepassados passaram - mostra como, mesmo em lugares distintos, a marginalização do povo negro é, muitas vezes, inevitável. De acordo com Eduardo David de Oliveira (2012, p. 29), a "diáspora é signo de movimentos complexos, de reveses e avanços, de afirmação e negação, de criação e mimese, de cultura local e global, de estruturas e singularidades, de rompimento e reparação"; ou seja, um movimento complexo e traumático como esse, que altera a cultura massiva de um país, certamente deixa rastros por muitos anos.

Em Ponciá Vicêncio, a presença e a ausência desses rastros são percebidas através da repressão, mas também da resistência. Conceição Evaristo, mulher negra nascida na metade do século XX em uma região periférica, fornece à literatura brasileira contemporânea uma perspectiva ampla da população negra dos últimos duzentos anos. Sua escrita está inserida no contexto da diáspora africana na América do Sul e da favelização, processo mais recente que faz com que muitos sujeitos afrodescentes sejam retirados dos centros urbanos. Ponciá Vicêncio fortalece a voz individual e coletiva da população negra no Brasil, reescrevendo um passado que foi negado, esvaziado e distorcido constantemente ao longo da história nacional. 


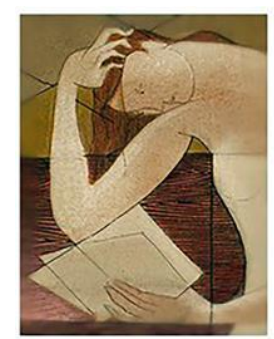

De acordo com Evaristo (2009, p. 17), em seu texto "Poética da Afrobrasilidade", as pessoas negras têm seu modo próprio de produzir e conceber o texto literário, com todas as implicações estéticas e ideológicas de sua experiência. Autores como ela, portanto, dão conta de alterar o estigma de uma literatura brasileira "abusivamente branca", como observou Cuti (2002, p. 32), mantendo o apagamento dos diversos autores afro-brasileiros que compõem nossa história. Assim, analisar a saga da família Vicêncio em busca de território, de pertencimento e de ascensão econômica e social na diáspora é uma das formas de reformular a memória negra no país.

\section{Primeiro movimento: a diáspora negra e a fabricação da raça}

A fragilização do território negro, desde a diáspora africana, é um fato consumado e definidor da experiência coletiva desses sujeitos ao longo da história. $\mathrm{O}$ sequestro transatlântico que provocou o deslocamento da população negra e sua consequente escravidão em terras estrangeiras é, para muitos, o ponto de partida de sua história e sua ascendência, posto que, seguidamente, é impossível rastrear sua origem para além daquele primeiro homem ou mulher que pisou em terras brasileiras. Assim, narrativa e território estão muito próximos, uma vez que o direito à terra e à moradia foi um dos grandes obstáculos que manteve a população negra, muitas vezes até os dias atuais, distantes dos centros sociais e do protagonismo historiográfico.

O movimento em massa de negros para o Brasil até o século XIX foi considerado, por anos, natural por conta de uma subversão do conceito de raça. Achille Mbembe (2017, p. 25), em "Crítica da razão negra", afirma que a raça é um complexo perverso gerador de medos e de tormentos, de problemas de pensamento e de terror, mas, sobretudo, de catástrofes. A diáspora negra ao Brasil foi, portanto, uma dessas catástrofes, que, ainda de acordo com o historiador, foi justificada pelo europeu colonizador como uma atitude "humanizadora e civilizatória" (MBEMBE, 2017, p. 28), uma vez que a narrativa construída por eles definia o negro como uma figura obscura e isolada. 


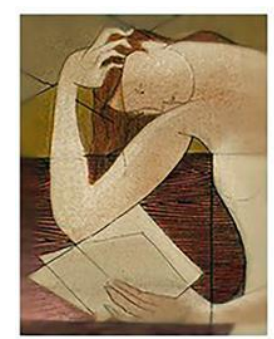

Dessa maneira, o sequestro de africanos foi justificado por uma noção de diferença construída pelo grupo que dominava as relações sociais e econômicas do período. Essa diferença, ainda, é um dos elementos que fundam o conceito de diáspora. De acordo com Stuart Hall (2003, p. 33), “o conceito fechado de diáspora se apoia sobre uma concepção binária de diferença. Está fundado sobre a construção de uma fronteira de exclusão e depende da construção de um 'Outro' e de uma oposição rígida entre o dentro e o fora". A naturalização da crueldade não se estabelece em uma sociedade de maneira arbitrária: ela é uma ficção útil produzida pelo discurso e pelas ações de determinado grupo que tem um objetivo bem delimitado. De acordo com Mbembe (2017, p. 27), o negro era considerado aquele sujeito que excedia na sociedade e não merecia, dessa forma, nem mesmo as condições básicas para uma existência digna:

A África, de um modo geral, e o Negro, em particular, eram apresentados como símbolos acabados dessa vida vegetal e limitada. Figura em excesso de qualquer figura e, portanto, fundamentalmente não figurável, o Negro, em particular, era o exemplo total deste ser-outro, fortemente trabalhado pelo vazio, e cujo negativo acabava por penetrar todos os momentos da existência.

Mbembe (2017, p. 42) reforça que a fabricação das questões de raça foi constante no século XIX, fazendo com que "os africanos e seus progenitores se tornassem escravos perpétuos", tendo uma condição de vida completamente distinta dos servos brancos que atendiam, algumas vezes, as mesmas famílias de senhores de escravos. No romance de Conceição Evaristo, a escravidão está representada majoritariamente - pelos avós da protagonista, que viveram como escravos e como homens libertos após a assinatura da Lei Áurea. Todavia, a degradação ontológica pela qual passaram e a falta de fiscalização da efetividade da lei fizeram com que, na prática, a lei fosse, de fato, apenas um papel vazio de sentido, e os antigos escravos continuassem a serviço do antigo senhor:

Tempos e tempos atrás, quando os negros ganharam aquelas terras, pensaram que estivessem ganhando a verdadeira alforria. Engano. Em muito pouca coisa a situação de antes diferia da do momento. As terras tinham sido ofertas dos antigos donos que alegavam ser presente de libertação. E, como tal, podiam ficar por ali, levantar moradias e plantar seus sustentos. Uma condição havia, entretanto, a de que continuassem todos a trabalhar nas terras do coronel Vicêncio. (EVARISTO, 2017, p. 42) 


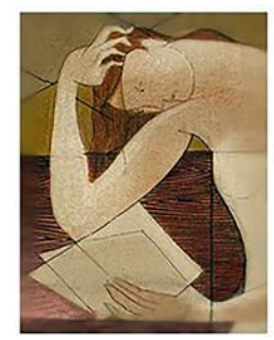

A alforria e a promessa de terras próprias foram, a princípio, motivo de comemoração pelos ex-escravos, mas concretamente significaram mudança nenhuma: a assinatura do documento que efetivaria a doação das terras nunca fora de fato posse de Vô Vicêncio e daqueles como ele, posto que "o coronel Vicêncio guardou os papéis e nunca mais a doação assinada voltou às mãos dos negros" (EVARISTO 2017, p.54), que permaneceram trabalhando nos engenhos de açúcar, os quais continuavam crescendo e "enriqueciam e fortaleciam o senhor" (EVARISTO, 2017, p.44). Portanto, como propôs Mbembe (2017, p.42), a plantação - de cana, de café ou outro produto transformou-se gradualmente em uma instituição não somente econômica, mas também social, disciplinar e penal. As plantações e seus donos não somente visavam ao lucro, mas tornavam seus, então, empregados, sujeitos submissos a uma lei própria que definia as condições de trabalho e a punição necessária àqueles que não a cumpriam, o que fez com que "os negros e os seus descendentes [fossem], desde então, comprados para sempre" (MBEMBE, 2017, p. 42).

No caso da família de Ponciá, a vigência da escravidão em anos de liberdade foi motivo, ainda, de um trauma particular: Vô Vicêncio, tendo filhos, mesmo que nascidos do "Ventre Livre", vendidos e vivendo as condições da escravidão após anos da Lei Áurea, "matou a mulher e tentou acabar com a própria vida. Armado com a foice que lançara contra a mulher, começou a se autoflagelar decepando a mão" (EVARISTO, 2017, p. 44-45). Pode-se afirmar que ato do avô, mesmo talvez inconscientemente, foi mais do que uma ação baseada na exaustão e decepção com a situação em que estava, foi a forma que a personagem encontrou de se rebelar contra seu senhor e cortar a parte do lucro que este tinha com sua família, visto que ele e a esposa eram reduzidos - assim como os outros sujeitos negros do período - ao seu trabalho. Com o braço "cotó", como apontado no romance, "tornou-se um estorvo para os senhores" (EVARISTO, 2017, p. 45) e teve uma vida ainda mais indigna, alimentando-se de sobras e catando restos da comida dada aos cães. Muitos anos após o ocorrido, Vô Vicêncio, neste momento dependendo de seus filhos que viviam em sua mesma condição anterior, "estava louco, chorando e rindo" (EVARISTO, 2017, p. 45) e continuava a vida que desejou acabar. Nesse sentido, o movimento que trouxe os africanos para o Brasil foi tão fundado em 


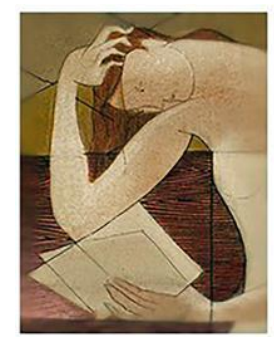

um processo de hierarquização racial, que a mudança nas leis foi insuficiente para que as práticas sociais se alterassem.

O pai de Ponciá, pertencente à geração seguinte à de escravos enganados pelo senhor, desde a infância era, pois, um homem livre. Entretanto, assim como seu pai, cresceu na fazenda dos Vicêncio, levando uma vida muito similar à do progenitor. Na infância, "era pajem do sinhô-moço. Tinha a obrigação de brincar com ele. Era o cavalo em que o mocinho galopava sonhando conhecer todas as terras do pai." (EVARISTO, 2017, p. 14). Os atos de crueldade a que era submetido eram constantes, e a humilhação que sofria não era apenas física, mas também moral, criando marcas em sua formação como sujeito e fazendo-o questionar, no momento e na vida adulta, se a liberdade anunciada era mesmo verdadeira:

Um dia o coronelzinho exigiu que ele abrisse a boca, pois queria mijar dentro. O pajem abriu. A urina do outro caía escorrendo quente por sua goela e pelo canto de sua boca. Sinhô-moço ria, ria. Ele chorava e não sabia o que mais lhe salgava a boca, se o gosto da urina ou se o sabor de suas lágrimas. Naquela noite teve mais ódio ainda do pai. Se eram livres por que continuavam ali? Por que, então, tantos e tantas negras na senzala? Por que todos não se arribavam a procura de outros lugares e trabalhos? (EVARISTO, 2017, p. 17)

$\mathrm{O}$ ato do "coronelzinho", notoriamente marcante pela perversidade, demonstra a força da lógica escravocrata, instalada até mesmo na mentalidade daqueles que nem mesmo viveram o período. De acordo Aníbal Quijano, em "Colonialidade del poder, eurocentrismo y America Latina", raça e identidade social foram estabelecidos como mecanismos de classificação social que, ainda em contexto capitalista, permeiam as relações sociais (QUIJANO, 2000, p. 202). O autor afirma que a inferioridade racial dos colonizados, portanto, definia que eles não eram dignos do trabalho assalariado, estando naturalmente obrigados a trabalhar em benefício de seus amos (2000, p. 207). Logo, o pai de Ponciá, desde a infância, esteve fadado a repetir a rotina do próprio pai, vivendo para seu senhor em troca de comida e moradia, sendo submetido ao trabalho exaustivo e, seguidamente, a ações torturantes e humilhantes. Essa personagem passa, apesar dos questionamentos surgidos na infância, a vida inteira na fazenda dos Vicêncio, uma vez que percebe que a lógica instaurada era maior do que ele, o que faz com que ele ficasse preso ao campo e àquelas relações de trabalho. Ponciá, por exemplo, "se lembrava 


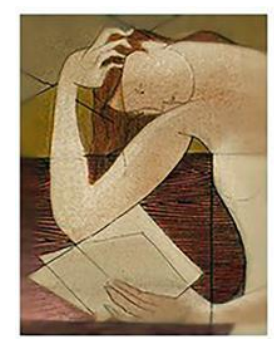

pouco do pai", uma vez que "o homem não parava em casa. Vivia constantemente no trabalho da roça, nas terras dos brancos. Nem tempo para ficar com a mulher e filhos o homem tinha" (EVARISTO, 2017, p. 17). Semeando ou colhendo, a personagem trabalhou na fazenda até que um dia, durante uma tarde de sol na colheita enquanto seus companheiros entoavam uma canção, "o pai de Ponciá Vicêncio foi se curvando, se curvando ao ritmo da música, mas não colheu o ritmo da terra, apenas à terra se deu" (EVARISTO, 2017, p. 28), deixando o filho, Luandi, regressar sozinho até a casa em que a mãe e a irmã viviam para anunciar o ocorrido.

A morte durante o trabalho é significativa, uma vez que, ainda que não seja possível afirmar com certeza a motivação do falecimento, provavelmente ela teve relação com as condições exaustivas e degradantes de seu trabalho. Ainda de acordo com Quijano (2000, p. 219), na América, a escravidão foi organizada e estabelecida com o intuito de produzir mercadorias para o mercado nacional e internacional, atendendo, nesse sentido, às necessidades do sistema capitalista. Ou seja, mesmo após a finalização da escravidão, o sistema escravocrata continuou suprindo demandas anteriormente estabelecidas. Segundo o autor (2000, p. 216), “con America se inicia, pues, un entero universo de nuevas relaciones materiales e intersubjetivas". Logo, o serviço análogo à escravidão não somente é uma lógica imposta para a manutenção do capitalismo instaurado, como também esse último se mantém pela subversão já construída de hierarquização racial, como conclui Quijano (2000, p. 203): "En America, la idea de raza fue un modo de ortogar legitimidad a las relaciones de dominación impuestas por la conquista".

A tentativa apontada por Quijano de tentar reduzir o negro à escravidão, todavia, não foi alcançada de maneira absoluta. A relação de sujeitos negros - africanos e seus descendentes - em diáspora, é analisada por Stuart Hall, que, além do caráter político, econômico e social abordado por Quijano, analisa a diáspora negra sob um ponto de vista cultural. Para o autor (2003, p. 27), "na situação da diáspora, as identidades se tornam múltiplas", fazendo com que a perspectiva diaspórica da cultura seja uma forma de subverter os "modelos culturais tradicionais orientados pela nação" (2003, p. 36). 


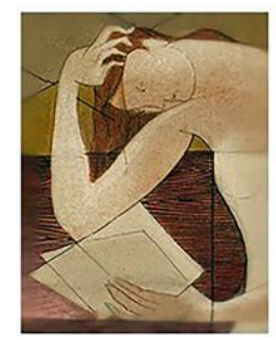

A cultura negra mantida ao longo dos anos na diáspora é uma maneira de manter a África viva e presente em território estrangeiro. As tradições familiares, a produção de objetos de barro, a religião seguida pela família e até mesmo as crenças de origem africana são comprovações de que a cultura da terra natal é passada pelas gerações e mantém viva uma memória imaterial do passado ancestral. Ponciá, por exemplo, na infância, tem medo de passar por baixo do arco íris, pois "diziam que menina que passasse por debaixo do arco-íris virava menino" (EVARISTO, 2017, p. 13). Essa lenda tem origem africana e faz referência ao orixá Oxumaré, a “cobra arco-íris", que, segundo a crença de algumas religiões de matriz africana, representa a mobilidade entre o sexo masculino e feminino, podendo ser, inclusive, associado à bissexualidade. A África, portanto, é mantida na memória da família de Ponciá, mesmo que essa seja nomeada "Vicêncio", em referência ao seu antigo senhor. Quando analisa a diáspora caribenha, Hall (2003, p. 40), pontua que, em território diaspórico, os sujeitos negros constroem sua própria cultura, e a diáspora, nesse sentido, não diz respeito somente àqueles que, primeiramente, cruzaram as fronteiras territoriais:

\begin{abstract}
A África passa bem, obrigado, na diáspora. Mas não é nem a África daqueles territórios agora ignorados pelo cartógrafo pós-colonial, de onde os escravos eram sequestrados e transportados, nem a África de hoje, que é pelo menos quatro ou cinco continentes diferentes embrulhados num só, suas formas de subsistência destruídas, seus povos estruturalmente ajustados a uma pobreza moderna devastadora. A "África" que vai bem nessa parte do mundo é aquilo que a África se tornou no novo mundo, no turbilhão violento do sincretismo colonial, reforjada na fornalha do panelão colonial.
\end{abstract}

Portanto, apesar da "produção do negro" apontada por Mbembe (2017, p.40), a história da população negra do Brasil é vasta e complexa, cultural e socialmente. Dessa forma, a trajetória percorrida de África para a América forjou os caminhos que, posteriormente, os negros em território brasileiro iriam percorrer. Em Ponciá Vicêncio, a diáspora é também a motivação inicial de outros movimentos, que são fruto das explorações mantidas em relação à população negra. Logo, a hierarquização das raças produzidas no período colonial mantém-se, até a atualidade, como um fator relevante de entendimento social. Por isso, a narrativa de Evaristo é tão importante: ela transpassa séculos de história, revisitando pontos apagados. 


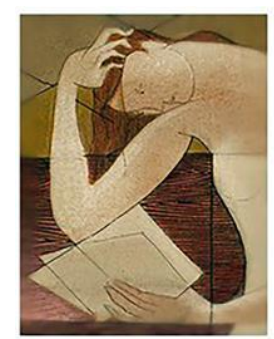

\section{Do campo à cidade: a imigração, esperança e marginalização}

Para Stuart Hall (2003, p. 45), sob o ponto de vista histórico, tanto a escravidão como o colonialismo fizeram com que a dispersão de sujeitos pelo globo fosse um dos assuntos mais importantes a serem observados na atualidade: os cruzamentos sociais e, consequentemente, culturais provocados pela diáspora e posteriores a ela refletem nas configurações da sociedade estruturada atualmente. Na perspectiva do autor, "os fluxos não regulados dos povos e culturas são tão amplos e tão irrefreáveis quanto aqueles patrocinados pelo capital e tecnologia" (HALL, 2003, p. 45). Assim, o sistema escravocrata e os anos seguintes a ele não foram momentos pontuais na história. Naturalmente, as relações econômicas e sociais iniciadas nesse período persistiram e motivaram a marginalização de sujeitos negros ao longo da história. Os movimentos que, segundo Hall, são naturais no funcionamento das sociedades, têm, nesse contexto, uma motivação ainda maior para acontecerem: a falta de condições financeiras de sujeitos negros, o que reflete na fragilização territorial percebida nesses grupos. No romance de Evaristo, essa fragilidade é marcada pela sujeição da família central a seus antigos senhores e acentuada pela morte do pai de Ponciá, responsável por parte significativa da renda familiar. A personagem, bem como seu irmão, migra para a cidade em busca de melhores condições de vida:

Quando Ponciá Vicêncio resolveu sair do povoado em que nascera, a decisão chegou forte e repentina. Estava cansada de tudo ali. De trabalhar o barro com a mãe, de ir e vir às terras dos brancos e voltar de mãos vazias. De ver a terra dos negros coberta de plantações, cuidadas pelas mulheres e crianças, pois os homens gastavam a vida trabalhando nas terras dos senhores e, depois, a maior parte das colheitas serem entregues aos coronéis. Cansada da luta insana, sem glória, a que todos se entregavam para amanhecer cada dia mais pobres, enquanto alguns conseguiam enriquecer a todos os dias. Ela acredita que poderia traçar outros caminhos, inventar uma vida nova. (EVARISTO, 2017, p. 30)

Percebendo a degradação do contexto no qual estava inserida, Ponciá decide deixar a terra onde vivia. A personagem percebe que o trabalho exaustivo - ao qual o pai foi submetido e a que seu irmão ainda era - não permitia que ela visse boas possibilidades de futuro. Ao seu redor, homens, mulheres e crianças estavam constantemente amarrados a um sistema passado regido pela mesma família de sujeitos brancos, que mandavam no solo e nas pessoas que ali viviam. A decisão da menina, de 


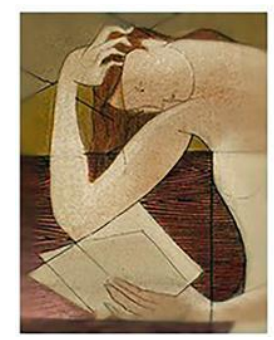

dezenove anos no momento, contrariou o desejo dos seus, que a lembraram dos "outros e outros casos de conhecidos que deixaram o povoado a caminho da cidade e eram roubados na estação de chegada" (EVARISTO, 2017, p.33) ou ainda daqueles que "ganhavam pouquíssimo e não tinham como viver", tendo uma "vida [que] se tornava pior do que na roça". Ponciá acreditou, contudo, que "o caso dela, quando voltasse para buscar os seus, haveria de ser uma história de final feliz" (EVARISTO, 2017, p. 33).

A esperança de um bom futuro longe do povoado onde vivia fez com que ela deixasse sua família para trás e, com um movimento motivado pelo medo de permanecer, imigra para a cidade, onde "não conhecia ninguém” (EVARISTO, 2017, p. 31). A trajetória de Ponciá foi imitada por seu irmão, um tempo depois que ela partira da roça. No romance, a presença de Luandi na cidade é anunciada in media res, quando ele já está instalado na zona urbana: "Luandi já estava na cidade havia anos. Chegara sozinho. Quando veio, pensava que seria só bater em algum lugar e se oferecer para trabalhar. Na roça trabalhava sempre" (EVARISTO, 2017, p. 59). Da mesma forma que seu pai, Luandi estava acostumado ao árduo trabalho da colheita de açúcar, mas, como a irmã, percebeu a impossibilidade de ascensão e de melhoria em suas condições de vida e, por isso, marchou para a cidade com a intenção de encontrar a dignidade que o campo impossibilitava:

Chegou ali sem eira e nem beira. Tinha perdido pelo caminho o endereço da irmã. Chegou num dia de chuva e frio. Trazia muita fome também. [...] Para que eu vim para a cidade, se perguntou novamente. Achar minha irmã, juntar dinheiro e ficar rico. É, ele havia de ficar rico. Diziam que na cidade as pessoas trabalham muito, mas ficam ricas. E de trabalho Luandi não tinha medo. (EVARISTO, 2017, p. 59)

Os objetivos dos irmãos, como se observa, eram bastante similares: alcançar uma posição social mais confortável e estar junto dos seus. Ambas as personagens buscam condições financeiras para, posteriormente, retornarem ao núcleo familiar de modo a permitir que aqueles que ficaram deixem o trabalho difícil do campo. Porém, eles encontram, já nos primeiros momentos fora de casa, a marginalização e a exclusão na cidade. Stuart Hall (2003, p. 28) pontua que "a pobreza, o subdesenvolvimento, a falta de oportunidades - os legados do império em toda parte - podem forçar as pessoas 


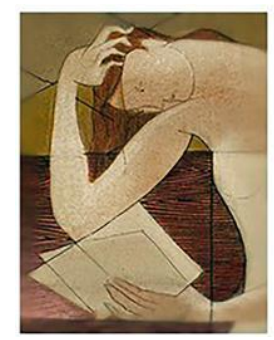

a migrar, o que causa o espalhamento - a dispersão. Mas cada disseminação carrega consigo a promessa de retorno redentor."

Ao pensar a diáspora, Hall conclui que povos negros descendentes do sequestro em África têm suas rotas marcadas por uma exclusão que permanece presente ao longo da história; o autor afirma que "suas 'rotas' são tudo, menos 'puras"” (HALL, 2003, p. 31). Quando pensamos a imigração do núcleo familiar de Ponciá para a cidade, ainda que essa nova rota tenha sido voluntária, percebemos que ela é fruto de uma situação degradante anteriormente estabelecida. De acordo com a historiadora Denise Rollemberg (1999, p. 43), nenhuma imigação acontece se são garantidas ao sujeito em questão uma vida "minimamente digna". Para a autora, o migrante é socialmente levado a escolher esse caminho devido a uma pressão econômica que assume um caráter social (1999, p. 42). As violências da migração, para ela, "estão presentes onde há pobreza, miséria e desemprego, fatores que motivam os processos migratórios” (1999, p. 43). No romance de Conceição Evaristo, no entanto, as personagens, na cidade, não encontram o sucesso almejado. Na primeira noite que passa nesse local, Ponciá dorme na rua, passa fome e frio e, no dia seguinte, pede emprego para diversas pessoas até receber uma indicação. Após conseguir o contato de uma senhora, em cuja residência Ponciá acabaria trabalhando como doméstica, ela passa alguns anos juntando dinheiro para poder sair da casa da patroa. Assim, mesmo que seu trabalho fosse assalariado, ela seguia vivendo em "terras" alheias, trabalhando em troca de comida, moradia e um baixo salário mensal.

Nesse momento, porém, a moça ainda "achava que a vida tinha uma saída. Trabalharia, juntaria dinheiro, compraria uma casinha e voltaria para buscar sua mãe e seu irmão" (EVARISTO, 2017, p. 38). Quando consegue, após muitos anos de trabalho, comprar seu "barraco" na favela, a personagem, já casada com um homem violento que "por qualquer coisa the enchia de socos e pontapés" (EVARISTO, 2017, p. 47), percebe que a felicidade almejada não chegara, e a miséria ainda a acompanhava. Ponciá, após perder sete filhos - recém nascidos ou ainda no ventre, por "complicações de sangue" -, chega a ponderar se essas ocorrências não foram positivas: 


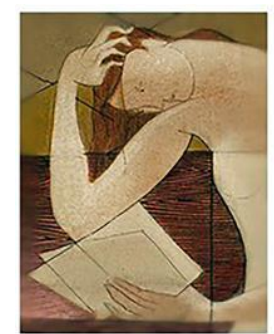

Bom mesmo que os filhos tivessem nascido mortos, pois, assim, se livraram de viver uma mesma vida. De que valera o padecimento de todos aqueles que ficaram para trás? De que adiantara a coragem de muitos em escolher a fuga, de viverem o ideal quilombola? De que valera o desespero de Vô Vicêncio? Ele, num ato de coragemcovardia, se rebelara, matara uns dos seus e quisera se matar também. O que adiantara? A vida escrava continuava até os dias de hoje. Sim, ela era escrava também. Escrava de uma condição de vida que se repetia. Escrava do desespero, da falta de esperança, da impossibilidade de travar novas batalhas, de organizar novos quilombos, de inventar outra e nova vida. (EVARISTO, 2017, p. 72)

A análise objetiva de Ponciá sobre sua condição é bastante significativa. Avaliar a perda dos filhos como positiva demonstra a incredulidade da personagem em uma possibilidade da ascensão social que ela objetivara no passado e pela qual lutou durante boa parte da vida.

A vida de seu irmão não foi totalmente diferente. A chegada de Luandi na cidade foi, como a de Ponciá, conturbada e, em seu caso, violenta. Por não ter onde passar a noite, resolveu deitar-se em um dos bancos da estação de trem e dormir ali até o dia amanhecer. "Foi acordado, entretanto, no meio do sono por um soldado" (EVARISTO, 2017, p. 60) e, imediatamente, considerado um criminoso, uma vez que não portava documentos de identificação - desnecessários e basicamente inexistentes no contexto em que anteriormente vivia.

Apesar de ter que acompanhar o soldado até a delegacia, Luandi se alegrou, pois percebeu que um dos soldados que o detiveram era, como ele, negro - "A cidade era mesmo melhor do que a roça. Ali estava a prova. O soldado negro! Ah! Que beleza! Na cidade, o negro também mandava!” (EVARISTO, 2017, p. 61). Soldado Nestor foi, a partir daí, uma figura modelo para Luandi, que decidiu ser também um soldado e começou a trabalhar na limpeza da delegacia. Contudo, mesmo com a ajuda daquele que considerava ser seu igual, Luandi estava em uma posição social em que quase nenhuma mobilidade social é possível. Como Ponciá, passa anos trabalhando na limpeza da delegacia e vive em um quarto muito pequeno. A mulher por quem se apaixonou na cidade, Biliza, trabalhava como prostituta em um local próximo à delegacia de Luandi e foi assassinada pelo dono da casa de prostituição. Luandi, nesse momento, estava ainda longe de sua família, trabalhando no mesmo cargo de anos anteriores. Com uma capacidade de leitura - necessária para o cargo de soldado - que se restringia a escrita e 


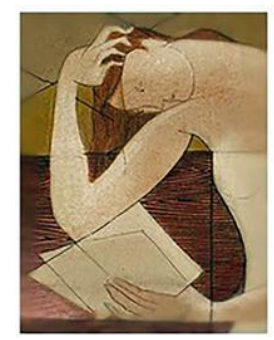

compreensão de poucas palavras, percebe que "a noite que trazia no peito haveria de se tornar mais noite ainda" (EVARISTO, 2017, p. 97). De acordo com Mbembe (2017, p. 46), "raça e racismos não pertencem, portanto, apenas ao passado. Têm também um futuro". O racismo proveniente da exploração negra e subjugação de sua raça, como se vê, manifesta-se também no contexto citadino em que os personagens aqui se encontram. Além de distantes de sua família, após anos na cidade, ainda não conseguiram conquistar um de seus objetivos centrais: a união familiar e o fim da miserabilidade.

Assim como pontua Mbembe, também Aníbal Quijano analisa a situação do negro após o fim da escravidão. Segundo o autor, há uma colonialidade do poder que permanece ativa nas sociedades capitalistas, em que a raça é um fator definidor da hierarquia social. Para ele, o sistema capitalista foi, desde o princípio, eurocentrado e, nesse sentido, branco (QUIJANO, 2000, p. 208). O autor afirma, nesta mesma seção de seu ensaio, que salários mais baixos são historicamente dados a pessoas de raças construídas como inferiores. Dessa maneira, ele associa as relações de trabalho à raça e, ainda, à geolocalização da população negra em contexto capitalista:

\begin{abstract}
Esa colonialidad del control del trabajo determinó la distribución geográfica de cada una de las formas integradas en el capitalismo mundial. En otros términos, decidió la geografía social del capitalismo: el capital, en tanto que relación social de control del trabajo asalariado, era el eje en torno del cual se articulaban todas las demás formas de control del trabajo, de sus recursos y de sus productos. (QUIJANO, 2000, p. 208)
\end{abstract}

Ou seja, em seu ponto de vista, aqueles detentores dos bens de consumo são, também aqueles que detém pessoas como objetos. Logo, o legado da escravidão, para Quijano, permanece socialmente ativo pela manutenção da ideia da raça negra como inferior: "en el control del sexo, de sus recursos y productos, la familia burguesa; en el control de la autoridad, sus recursos y productos, el Estado-nación; en el control de la intersubjetividad, el eurocentrismo" (QUIJANO, 2000, p. 214). Mais do que as relações trabalhistas e, consequentemente, financeiras, para Quijano, os sujeitos brancos são detentores da intersubjetividade nas interações sociais: uma nova forma de exploração se articula com a identidade racial formada ao longo da história. Luandi e Ponciá, na cidade, estão, pois, submetidos a novas situações de exploração; sua raça, porém, 


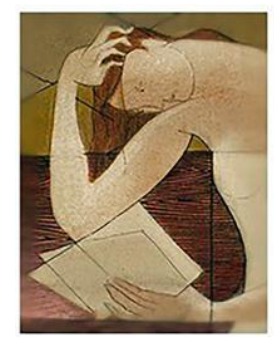

permanece no mesmo local hierárquico de antes. Para Stuart Hall (2003, p. 41), a África - em diáspora - segue sendo uma metáfora para exclusão: “África é o significante, a metáfora para aquela dimensão de nossa sociedade e história que foi maciçamente suprimida, sistematicamente desonrada e incessantemente negada, e isso, apesar de tudo que ocorreu, permanece assim". Com a imigração, o trajeto já extenso da família Vicêncio se expande, sem, contudo, ter significativas mudanças, não somente para eles, mas para aqueles que estavam ao seu redor.

Além dos ambientes degradantes em que se encontravam e da situação econômica bastante ultrajante, a condição identitária dos migrantes aqui analisados é conflitante. Infelizes na cidade, a saudade da terra natal se intensifica. A falta da mãe, da convivência com os seus, do barro - no caso de Ponciá - faz com que eles retornem, algumas vezes, ao campo com a intenção de visitar a mãe. Todavia, em ambas as vezes que Ponciá retorna, há um desencontro: a mãe, com a saída dos filhos, sentiu-se como eles e passou a perambular pelas terras de vizinhos, vendendo os artefatos de barro produzidos e buscando companhia. Isso fez com que, no retorno dos filhos, eles achassem apenas a casa vazia com alguns sinais de que ela por ali estivera.

Em uma de suas visitas, Ponciá visitou vários vizinhos, encontrando em todas as casas trabalhos de barro produzidos anteriormente por ela e pela mãe. Nas conversas com eles, ouvia histórias sobre esses sujeitos, bem como sobre sua própria família, "remendando cuidadosamente o tecido roto de um passado, como alguém que precisasse recuperar a primeira veste, para nunca mais se sentir desamparadamente nua" (EVARISTO, 2017, p. 55). O desejo de retorno também é experienciado pelo irmão. Soldado Nestor, ao perceber a tristeza de Luandi - que estava com o "coração tão carregado" (EVARISTO, 2017, p. 94) - entende que o sentimento provinha da falta dos seus, uma vez que ele "sabia por experiência própria o que era ser uma pessoa sozinha, ele também vivia longe do seu clã" (EVARISTO, 2017, p. 94). A desconexão com a terra é, também, uma desconexão com sua ancestralidade. De acordo com Rita OlivieriGodet (2010, p. 192), a migrância está intimamente ligada ao sentimento de deslocamento identitário: 


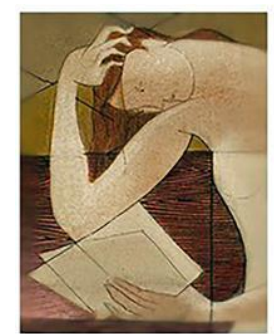

A migrância busca dar conta das mutações da subjetividade no contexto das nossas sociedades pós-coloniais, no qual, por razões diversas, políticas, econômicas, culturais ou outras, o ser humano vive em deslocamento. Deslocado, desabrigado, o homem não possui mais um lugar onde possa se sentir em casa.

A instabilidade em relação ao território que ocupam é, portanto, uma instabilidade também emocional. As narrativas de imigração, que, segundo Pierre Ouellet (2013, p. 158), são "histórias de despossessão e expropriação", nascem, pois, da violência e podem ser vividas de modo bastante negativo, que se concretiza pela "perda de si”. Ponciá e Luandi, com frágeis relações sociais estabelecidas e sem o apoio de um grupo, como o que tinham na roça, sentem-se perdidos no ambiente citadino, que pode ter trazido algumas vitórias - como a compra da casa de Ponciá e, no caso de Luandi ao fim o romance, a conquista do cargo de soldado -, mas não supriram as necessidades emocionais. A saudade de que padeciam não era apenas uma saudade da mãe, mas de um ambiente em que o senso de comunidade estava claro, onde havia a ajuda de umas pessoas em relação a outras, onde eram reconhecidos como filhos de alguém, como netos de Vô Vicêncio. A solidão dos personagens na cidade mostra que, da mesma maneira que, na roça, não lhes foi garantida a segurança que mereciam, o que fez com que se sentissem incompletos nesse local. Ouellet aponta que os sujeitos migrantes, seguidamente, "encontram-se despedaçados ou fragmentados e pelo menos contraídos entre os diferentes lugares e os diferentes tempos que ocupam e os ocupam" (OUELLET, 2013, p. 156). Nesse sentido, a cidade e o campo existem no imaginário dos irmãos, que estão, ao imigrarem, situados em um espaço-tempo em suspensão, posto que não encontraram na cidade a ascensão que buscavam, nem percebem o campo como o local ideal para o qual podem retornar, uma vez que, na roça, a exploração permaneceria vigente. A cidade é, para eles, local de deslocamento:

Não há mais lugar próprio ao deslocamento, não há território para a passagem: nada além de um vasto corredor no tempo, que liga um passado morto e um futuro ainda não nascido, em um presente sobrecarregado de ausências, sem presença verdadeira senão profundamente esburacada pelos lugares abandonados e por aqueles que não lhe são ainda dados, e sem dúvida não o serão jamais. O deslocado faz um buraco no tempo e no espaço, onde ele vive e sobrevive, entre uma memória e uma esperança, que não formam em parte alguma um território. (OUELLET, 2013, p. 147-148) 


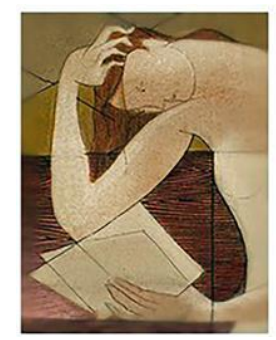

O movimento dos personagens para a cidade, portanto, reafirmou a construção histórica da posição do negro no país. Na cidade ou no campo, os personagens viveram em posição de subalternidade, provando o não pertencimento deles em diferentes espaços do território nacional.

\section{Travessia final e o retorno possível.}

Nas últimas páginas do romance, o encontro entre o núcleo familiar levanta novas possibilidades de futuro. Maria, mãe de Luandi e Ponciá, após um período de deambulação pelas terras do povoado onde vivia, decide ir à cidade em busca dos filhos. Para isso, ela consulta Nêngua Kainda, uma senhora sábia da região que portava as tradições do passado e conseguia, segundo a crença de todos, adivinhar o futuro. A personagem, que já havia feito algumas constatações sobre a impossibilidade de reencontro familiar nas situações anteriores, agora confirma que chegara a hora de Maria ir "buscar os filhos".

A errância da mãe pelo povoado, portanto, funcionou como uma espécie de preparação para essa travessia campo-cidade, posto que ela, diferente dos filhos, não objetivava viver na cidade: "Se sua vida era a da terra, em que ela vivia, o que faria agora longe de lá? Entretanto, se preparava para se afastar do lugar em que havia nascido. Da terra que guardava seu umbigo, que ali fora enterrado selando, pois, a filiação dela com o solo do povoado" (EVARISTO, 2017, p. 90). Ela, nesse período, ia a cada vez um pouco mais longe, retornando a sua casa e partindo novamente, em cada trecho "aumentava a distância do ponto original, avançando um pouco mais na rota em busca dos filhos" (EVARISTO, 2017, p. 91).

O desenraizamento de Maria combina com o de seus filhos: Luandi, sem Biliza, sentia-se sozinho e isolado na cidade, e, mesmo com medo do regresso, "sentia de voltar ao povoado" (EVARISTO, 2017, p. 94). Ponciá, infeliz com sua condição, sentia saudade da vida no povoado: "a saudade que ela dizia sentir do pai e do avô mortos, da mãe e do irmão desaparecidos. Ela às vezes dizia também que tinha saudade do barro e, de tempo em tempo, apresentava um incômodo entre os dedos que coçava até sangrar" 


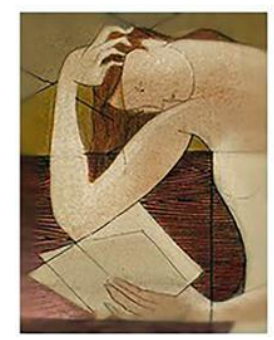

(EVARISTO, 2017, p. 93). O retorno, pois, é um desejo - seguidamente - de muitos migrantes. Godet (2010, p. 204) pontua que "a nostalgia do país de origem é uma armadilha da memória afetiva que captura o sujeito num passado imóvel que lhe dá segurança". Ainda que, naturalmente, a vida do povoado tenha se alterado, aquilo que ele simboliza permanece imóvel para os personagens. Sua identidade está conectada à terra, que é o elemento que os une e faz com que sintam que têm, apesar da distância e dos descaminhos percorridos, um ponto de encontro. No povoado, diferentemente da cidade, onde não estabelecem muitas relações de amizade, eles têm amigos, considerados por eles irmãos - "todos eram parentes por ali” (EVARISTO, 2017, p. 51). De acordo com Hall (2003, p. 29), em diáspora, possuir uma identidade cultural é "estar primordialmente em contato com um núcleo imutável e atemporal, ligando ao passado o futuro e o presente numa linha ininterrupta”. Para Hall, esse núcleo é o continente previamente ocupado pelos sujeitos em diáspora, que, no romance de Evaristo, pode ser representado pelo povoado campesino, dado que é nele que se encontram não só os familiares dos personagens, mas também o início de sua história, que está nas lendas, nas tradições, nas crenças religiosas, nas previsões de Kainda. A rota iniciada em África tem uma parada significativa no povoado, que representa as raízes de Maria, Ponciá e Luandi.

Luandi, após o reencontro com a mãe, e o recebimento do título de soldado, que almejara por anos, Luandi foi designado a atuar na estação de trem:

O primeiro local, fora da delegacia, em que Soldado Luandi José Vicêncio tiraria serviço seria na estação. Quando o delegado lhe fez o comunicado, sentiu um certo prazer. Viveria aquele lugar, mas de um outro modo. Não era alguém que chegava. Era alguém que estava. Era uma pessoa que se impunha. (EVARISTO, 2017, p. 105)

Nesse primeiro dia se serviço, como aquele que finalmente havia conquistado um lugar próprio onde poderia permanecer, Luandi encontra a irmã. Ponciá, que há anos se "afastava de si", recebendo a herança de Vô Vicêncio - que pode ser entendida tanto como a loucura quanto como uma sensibilidade aguçada frente aos problemas enfrentados. A personagem estava vagando pelo local, andando de um lado para o outro, rindo e chorando, com o objetivo de "tomar o trem, voltar ao povoado, voltar ao rio" 


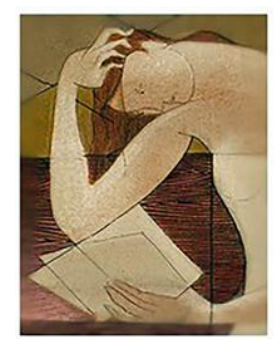

(EVARISTO, 2017, p. 104). O desejo de voltar ao rio é um desejo de voltar às raízes. Ao notar a irmã, rindo, chorando e falando sozinha no local,

Luandi acercou-se carinhoso da irmã dizendo-lhe que sabia o caminho do rio e que haveria de levá-la. Ponciá Vicêncio levantou os olhos para ele, mas não se podia dizer se ela o havia reconhecido ou não. Abriu, porém, a trouxa, tirou o homem-barro e perguntou ao irmão se ele se lembrava de Vô Vicêncio. (EVARISTO, 2017, p.104)

O reencontro de Ponciá com a mãe ocorreu na sequência ao encontro com o irmão. Desejando o retorno ao povoado, percebe-se que a memória da personagem em relação ao local é similar à do irmão e a de sua mãe, que veem o lugar como o local em que sua identidade cultural está, mesmo que essa tenha sido reprimida ao longo dos anos. Para Homi Bhabha (1998, p. 241), “a cultura é tradutória”, e isso ocorre porque as narrativas de deslocamento - constantes no tempo e na história - centralizam-se na cultura, em seu significado. No romance de Evaristo, essa centralidade parece estar firmada. Tanto Ponciá quanto Luandi, apesar de seu longo percurso na cidade, optaram pelo retorno. Luandi, que recém conquistara o cargo de soldado, percebe que a posição não lhe garantiria o futuro que desejou, sendo, na verdade, apenas um passo para o lado, não para a frente, e, mesmo tendo uma posição de mando ocasional, ele ainda seria, como antes, subalterno:

E ele, que queria tanto ser soldado, mandar, bater, prender, de repente descobria que nada valia a realização de seus desejos, se fossem aqueles os sentidos de sua ação, de sua vida. Soldado Nestor era tão fraco e tão sem mando como ele. Apenas cumpria ordens, mesmo quando mandava, mesmo quando prendia. Foi preciso que a herança de Vô Vicêncio se realizasse, se cumprisse na irmã para que ele entendesse tudo. Só agora atinava também as palavras de Nêngua Kainda. Ele que levara tanto tempo desejando a condição de ser soldado, em poucos minutos escolhia desfazer-se dela. (EVARISTO, 2017, p. 109)

O local de partida é, pois, também o de retorno. Ainda que o povoado certamente houvesse se alterado ao longo do tempo, uma vez esse local da lembrança somente existe na memória das personagens, ambas percebem que, em qualquer território, sua condição social e econômica se manteria, mas sua identificação e suas raízes eram fixas. Essa condição, todavia, novamente demonstra a fragilidade territorial do povo negro, situação que se estende para fora da literatura. Os irmãos Vicêncio foram ativos na busca por melhores condições de vida, migraram, trabalharam 


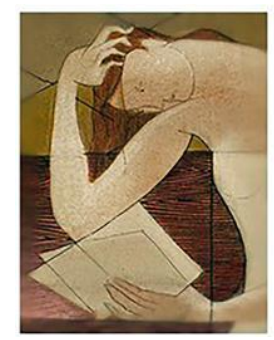

severamente e, ainda assim, concluíram que retornar ao local de partida seria a opção mais interessante para ambos. Naturalmente, esse percurso de retorno às raízes é significativo para a construção da narrativa, em que memória e história estão imbricadas; porém, também é significativo notar que o retorno ao povoado, sob uma perspectiva histórica, é um retorno, também, ao antigo funcionamento de uma sociedade em que o conceito de raça, como propôs Quijano (2000), define as relações sociais e econômicas. Por conta disso, o romance de Conceição Evaristo dá conta de construir uma trajetória que, apesar de única - posto a singularidade da família Vicêncio, de sua cultura, de suas crenças e tradições - também constrói uma história nova para homens e mulheres negros que, ao protagonizarem o romance, tornam-se o centro de uma nova história.

\section{Considerações finais}

Diáspora e migração são movimentos comuns nas sociedades modernas e antigas; contudo, o apagamento de determinados núcleos sociais também é. O romance de Conceição Evaristo, Ponciá Vicêncio, nesse sentido, revela o compromisso da autora com a representação de personagens negros como figuras capazes de ter uma subjetividade particular conectada a uma cultura rica. Assim, Evaristo é promotora da visibilidade que os registros históricos, seguidamente, parecem esquecer. A narrativa não deixa de ser, portanto, um romance de formação, à medida que representa a história de uma família através do tempo, perpassando momentos históricos diversos sob um ponto de vista muitas vezes negado.

Por meio das lembranças-esquecimentos de Ponciá e de sua família, percebemos que a narrativização de histórias como essa é essencial para que ocorram transformações sociais, uma vez que a apreensão da realidade se expande. A diáspora africana representada por todos os personagens, mas, principalmente pelos anciãos da família Vicêncio, mostra a força do escravismo, inalterado muitos depois da emancipação dos escravizados. Nesse contexto, é evidente que o sistema foi mantido pela força de poder da raça branca, que ainda era detentora do poder - naquela e em outras regiões. 


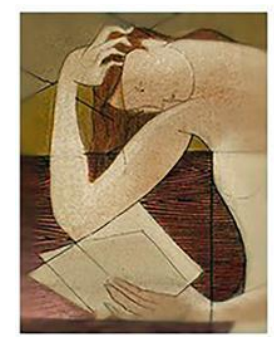

$\mathrm{O}$ ato de rebeldia de Vô Vicêncio, assassinando sua esposa e decepando o próprio braço, é essencial para a compreensão da violência naturalizada do período, uma vez que a subjugação de sua família era tão grande, que ele se rebelou contra os seus, talvez por não ter força de agir contra o senhor da fazenda. O trauma que está na fundação da história da família, pois anuncia também a herança deixada pelo avô para Ponciá: a percepção sensível sobre o mundo leva a personagem ao esquecimento e à loucura.

A travessia campo-cidade-campo, portanto, é um dos elementos que representam o processo de desterritorialização do negro, que se mantém, apesar de suas tentativas, à margem da sociedade. Embora não saibamos exatamente o local em que Luandi se instala na cidade, sabe-se que essa é uma região precária e pobre. Ponciá, por sua vez, é afastada para a favela, longe da parte organizada e estável da cidade. A personagem narra a história de vizinhos, que, vítimas e também atores de violência, sofrem expulsões diárias e, algumas vezes, cometem crimes como estratégia de sobrevivência. Luandi, mesmo quando assume a posição de soldado, almejada por anos, percebe que jamais teria as mesmas possibilidades que seus colegas brancos.

Logo, o terceiro movimento definitivo dos personagens é o retorno ao campo, que, em certa medida, pode representar também um retorno às condições do passado. Porém, esse trajeto também significa um reencontro com as raízes, com seus irmãos e irmãs do povoado, com a cultura que deixaram para trás, com a mãe. O povoado é o núcleo cultural que fornece, a eles, pertencimento. Assim, o que se percebe em Ponciá Vicêncio é a construção da memória familiar de uma família negra, que, como muitas outras, foi deixada não só nas margens territoriais como nas margens da história.

Conceição Evaristo, mulher negra cumpre o papel de, nesse romance, reescrever a história negada a muitos povos, apresentando um romance que contempla diferentes gerações e as dificuldades particulares de todas elas. Ao recontar o passado a partir da apresentação sensível da subjetividade do homem e da mulher negra, o romance faz com que a revisão dos acontecimentos históricos seja ainda mais significativa. Assim, a afirmação de Achille Mbembe (2017, p. 54) de, “apesar da dispersão, uma longa tradição de co-identificação e de respeito mútuo terá caracterizado as relações dos 


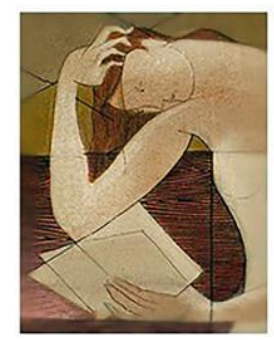

Negros entre si", pode ser expandida ao romance de Evaristo, uma vez que, nele, a história coletiva e as vozes individuais da população negra estão sensivelmente representados.

\section{Referências}

BHABHA, Homi. O local da cultura. Trad. Myriam Ávila, Eliana Lourenço de Lima Reis e Gláucia Renate Gonçalves. Belo Horizonte: UFMG, 1998.

CUTI, Luiz Silva. O leitor e o texto afro-brasileiro. In: FIGUEIREDO, Maria do Carmo Lana; FONSECA, Maria Nazareth Soares (org.) Poéticas afro-brasileiras. Belo Horizonte: Editoria PUC Minas, Mazza Edições, 2002.

EVARISTO, Conceição. Gênero e Etnia: uma escre(vivência) de dupla face. Texto apresentado na mesa de escritoras convidadas do X Seminário Nacional Mulher e Literatura - I Seminário Internacional Mulher e Literatura, UFPB, 2003. Disponível em: http://nossaescrevivencia.blogspot.com/2012/08/genero-e-etnia-uma-escrevivenciade.html. Acesso em: $16 \mathrm{dez} 2019$.

- Literatura Negra: uma poética de nossa afro-brasilidade. Belo Horizonte: Scripta, v. 13, n. 25, p. 17-31, 2. sem. 2009.

Ponciá Vicêncio. Rio de Janeiro: Pallas, 2017.

GODET, Olivieri Rita. Errância / migrância / migração. In: BERND, Zilá (Org.). Dicionário das mobilidades culturais: percursos americanos. Porto Alegre: Literalis, 2010.

HAESBAERT, Rogério. O mito da desterritorialização. Rio de Janeiro: Bertrand Brasil, 2014.

HALL, Stuart. Pensando a diáspora (Reflexões sobre a terra no exterior). In: $D a$ Diáspora: Identidades e Mediações Culturais. Liv Sovik (org.); Trad. Adelaine La Guardia Resende. Belo Horizonte: Editora UFMG, 2003.

MBEMBE, Achille. Crítica da Razão Negra. 2 ed. Trad. Marta Lança. Lisboa: Antígona, 2017.

OLIVEIRA, Eduardo. Filosofia da ancestralidade como filosofia africana: Educação e cultura afro-brasileira, Revista Sul-Americana de Filosofia e Educação (RESAFE), n. 18, p. 28-47, Outubro. 2012. 


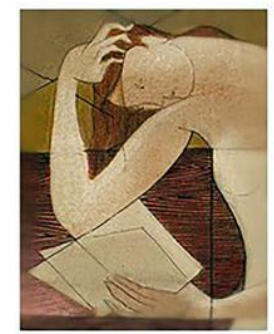

OUELLET, Pierre. Palavras migratórias. As identidades migrantes: a paixão do outro. In: HANCIAU, Nubia; DION, Sylvie (Orgs.). A literatura na história, a história na literatura. Rio Grande: Editora da FURG, 2013.

QUIJANO, Aníbal. Colonialidad del poder, eurocentrismo y América Latina. In: LANDER, Edgardo (Org.). La colonialidad del saber: eurocentrismo y ciências sociales. Perspectivas Latinoamericanas. Buenos Aires: CLACSO, Consejo Latinoamericano de Ciencias Sociales, 2000.

ROLLEMBERG, Denise. Exílio: entre raízes e radares. Rio de Janeiro: Record, 1999. 